\title{
UJI AKTIVITAS ANTIOKSIDAN EKSTRAK DAUN LIDAH MERTUA (Sansevieria masoniana Chahin) DENGAN METODE DPPH(1,1-Difenil-2- Pikrilhidrazil)
}

\author{
ANALYSIS OF ANTIOXIDANT ACTIVITY OF LIDAH MERTUA LEAVES \\ (Sansevieria masoniana Chahin) EXTRACT USING DPPH (1,1-Difenil-2- \\ pikrilhidrazil) ASSAYS
}

\author{
Anita Rasuna Sari Siregar ${ }^{1}$, Mawardi $^{2}$, Elfrida ${ }^{3}$ \\ Jurusan Pendidikan Biologi Fakultas Keguruan Dan Ilmu Pendidikan \\ Universitas Samudra \\ Email: rasuna23@gmail.com
}

\begin{abstract}
ABSTRAK
Sansevieria adalah salah satu tanaman hias yang memiliki aktivitas antioksidan. Salah satu spesies dari genus sansevieria adalah Sansevieria masoniana Chahin yang diduga memiliki aktivitas antioksidan. Aktivitas antioksidan speies sansevieria ini masih belum diketahui sehingga perlu dilakukan penelitian. Penelitian ini bertujuan untuk menguji aktivitas antioksidan ekstrak daun lidah mertua (Sansevieria masoniana Chahin). Ekstrak daun lidah mertua (Sansevieria masoniana Chahin) diperoleh melalui metode maserasi menggunakan pelarut etanol 96\% . Ekstrak yang telah diuapkan pelarutya hingga menjadi ekstrak kental kemudian dilakukan skrining fitokimia, hasil skrining ekstrak menunjukkan positif mengandung flavonoid dan saponin. Kemampuan ekstrak sebagai antioksidan ditentukan melalui peredaman radikal DPPH (1,1-difenil-2-pikrihidrazil) terhadap variasi konsentrasi ekstrak 12,5 ppm, 25 ppm, 50 ppm, 100 ppm, dan 200 ppm. Hasil akhir dari uji DPPH tersebut ialah radikal berubah warna dari ungu menjadi kuning dan serapannya diukur dengan spektrofotometer UV-Vis pada panjang gelombang $517 \mathrm{~nm}$. Hasil uji aktivitas antioksidan yang dilakukan menghasilkan nilai IC $_{50}$ sebesar 97,902 ppm yang menunjukkan bahwa aktivitas antioksidan ekstrak Sansevieria masoniana Chahin memiliki aktivitas antioksidan yang kuat.
\end{abstract}

Kata kunci: Aktivitas antioksidan, ansevieria masoniana, DPPH.

\section{ABSTRACT}

Sansevieria is an ornamental plant that has antioxidant activity. One species of the genus Sansevieria is Sansevieria masoniana Chahin which is thought to have antioxidant activity. The antioxidant activity of this species of Sansevieria is still unknown, so research is needed. This study aims to examine the antioxidant activity of the extract of the tongue-in-law (Sansevieria masoniana Chahin). Aloe-in-law leaf extract (Sansevieria masoniana Chahin) was obtained through the maceration method using $96 \%$ ethanol solvent. Extracts that have evaporated their solvents into thick extracts are then subjected to phytochemical screening, extract screening results show positive containing flavonoids and saponins. The ability of the extract as an antioxidant was determined by reducing the DPPH radical (1,1-diphenyl-2-picrihydrazyl) against variations in the extract concentration of $12.5 \mathrm{ppm}, 25 \mathrm{ppm}, 50 \mathrm{ppm}, 100 \mathrm{ppm}$, and 200 ppm. The final result of the DPPH test is that the radicals change color from purple to yellow and their absorption is measured by a UV-Vis spectrophotometer at a wavelength of $517 \mathrm{~nm}$. The results of the antioxidant activity test carried out resulted in an IC50 value of 97.902 ppm which indicated that the antioxidant activity of the Sansevieria masoniana Chahin extract had strong antioxidant activity.

Keyword: Antioxidant activity, Sansevieria masoniana, DPPH. 


\section{PENDAHULUAN}

Antioksidan merupakan senyawa kimia yang dapat mendonorkan elektron pada radikal bebas yang reaktif agar tidak reaktif dan stabil sehingga dapat mencegah proses oksidasi dalam tubuh (Tamat et al., 2007; Aji, 2014). Beberapa sumber radikal bebas adalah asap rokok, pestisida, polusi udara, makanan yang dibakar dan ozon (Hayati,2011; Tapan,2005; Pratama et al., 2010).

Manusia memiliki sistem pertahaan endogen sendiri untuk menangkal senyawa radikal bebas yang terbentuk oleh berbagai enzim, seperti glutathione, peroksidase, catalase, dan seperoxydedismutas yang membentuk senyawa antioksidan namun, efektivitasnya masih kurang akibat tidak sebandingnya dengan jumlah serangan radikal bebas dari lingkungan yang masuk kedalam tubuh, oleh sebab itu diperlukan senyawa antioksidan eksogen (Umayah \& Amrun,2007; Winarsih,2007; Marmi, 2013). Antioksidan dari luar tubuh( eksogen) bisa didapatkan secara alami dari alam seperti tanaman yang berfungsi sebagai antioksidan maupun antioksidan secara sintetik ( Julfitriyani et al., 2016; Aqil et al., 2006; Jin et al., 2012). Penggunaan antioksidan sintetik bersifat karsinogen dan dalam jangka tertentu dapat menyebabkan keracunan bagi tubuh (Jin et al., 2012; Wahdaningsih, 2011). Penggunaan antioksidan secara alami seperti dari tanaman tertentu mulai banyak dikembangkan. Tanaman dengan kandungan senyawa metabolit seperti, flavonoid, alkaloid, saponin, tanin, steroid/triterpenoid dapat menghambat adanya paparan radikal bebas (Handayani, Ahmad, and Sudir 2014; Ismail et al. 2012; Widowati 2011). Berdasarkan senyawa metabolit yang terkandung tanaman dari genus Sansevieria diduga memiliki aktivitas antioksidan.

Dalam penelitian (Pratama et al., 2010), menyatakan bahwa sanseveria cylindrica memiliki senyawa aktif antioksidan berupa senyawa alkaloid, saponin dan flavanoid dengan uji fitokimia. Berdasarkan penelitian (Dewatisari et al.,2017)pada sansevieria trifasciata var. Laurentii dan sanseveria cylindrica menunjukkan kandugan fitokimia alkaloid, triterpenoid, flavanoid, steroid, yang mempunyai kemampuan sebagai antioksidan. Namun informasi mengenai aktivitas antioksidan dan antikanker dari salah satu spesies Sansevieria yaitu Sansevieria masoniana Chahin belum diketahui, padahal pengetahuan mengenai tumbuhan ini penting untuk diketahui sehingga dapat menjadikan tanaman genus Sansevieria sebagai tanaman sumber antioksidan. Pemakaian tumbuhan Sansevieria dalam penelitian juga didasarkan karena tumbuhan ini mudah untuk ditemukan di wilayah tropis seperti di Indonesia sehingga efisien dan murah untuk dijadikan sampel penelitian.

Berdasarkan uraian diatas, maka dilakukan uji aktivitas antioksidan dari daun 
Sansevieria masoniana Chahin. Kadar antioksidan dalam Sansevieria masoniana Chahin dapat diuji dengan berbagai macam metode salah satunya adalah metode 1,1difenil-2-pikrilhidrazil, metode ini dipilih karena pengerjaannya yang sederhana dan mudah, dengan uji menggunakan radikal DPPH

\section{METODOLOGI PENELITIAN}

\section{Alat dan Bahan}

Alat-alat yang digunakan adalah rotary evaporator, timbangan analitik, blender, gelas beaker, spektrofotometer UV-Vis, water bath, mikro pipet, pipet tetes, tabung reaksi, spatula, magnetic stirrer, alumunium foil, rak tabung reaksi, corong kaca, pisau, nampan. Bahan yang digunakan ialah daun lidah mertua (Sansevieria masoniana Chahin), etanol 96\%, DPPH (1,1- difenil-2-pikrihidrazil), $\mathrm{H}_{2} \mathrm{SO}_{4}$, aquades, HCL, pereaksi lieberman burchard, Pereaksi salkowsky, pereaksi bouchardat, pereaksi meyer, $\mathrm{CeSO}_{4}, \mathrm{FeCl}_{3}$.

\section{Pengambilan Sampel}

Sampel yang digunakan berupa daun tanaman lidah mertua (Sansevieria masoniana Chahin) yang berada di daerah stabat.

\section{Preparasi Sampel}

Daun lidah mertua (Sansevieria masoniana Chahin) segar $7 \mathrm{Kg}$

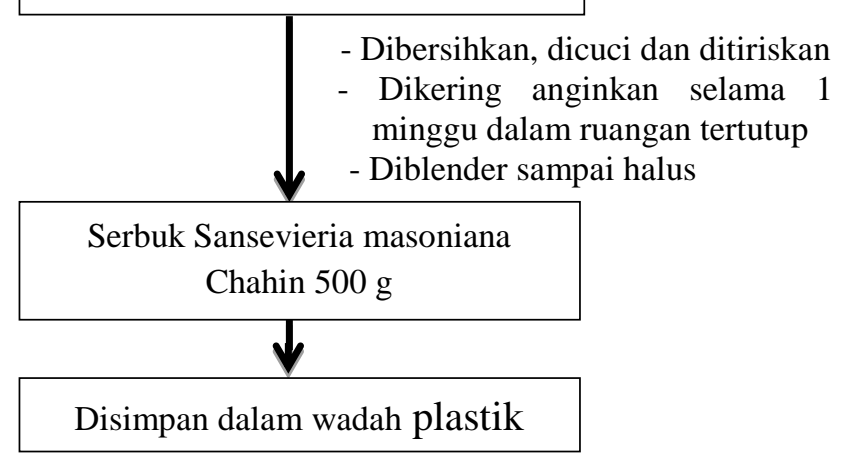

(1,1- difenil-2-pikrihidrazil) melalui cara ini antioksidan akan menurunkan jumlah radikal bebas DPPH yang serapannya diukur dengan spektrofotometer UV-Vis. Metode ini sudah terbukti akan keakuratannya(Marxen et al. 2007; Pratimasari 2009).

\section{Ekstraksi}

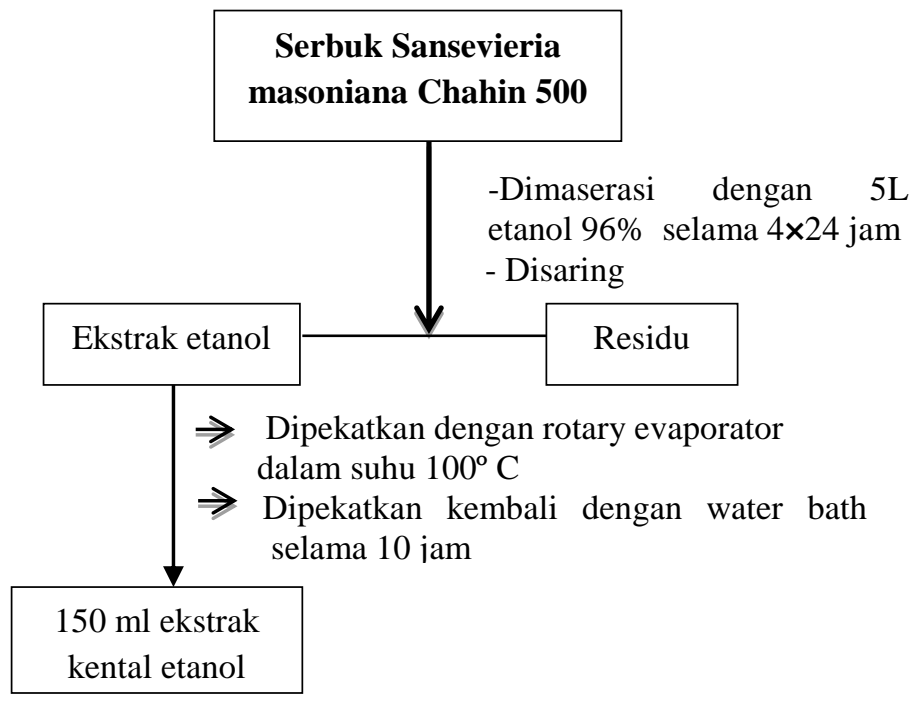

\section{Uji Fitokimia}

Dilakukan uji flavonoid, saponin, terpenoid, steroid, alkaloid dan tanin terhadap ekstrak daun lidah mertua (Sansevieria masoniana Chahin). Uji flavonoid dilakukan dengan $\mathrm{H}_{2} \mathrm{SO}_{4}$, uji saponin dilakukan dengan aquades, alkohol dan HCL, uji terpenoid menggunakan pereaksi liebermann- burchard, uji steroid dilakukan dengan pereaksi liebermannburchard, uji alkaloid dilakukan dengan HCL, pereksi bouchardart dan pereaksi meyer, uji tanin dilakukan dengan $\mathrm{FeCl}_{3}$ (Harborne, 1987). 
Uji Aktivitas Antioksidan

\section{Pembuatan Larutan DPPH}

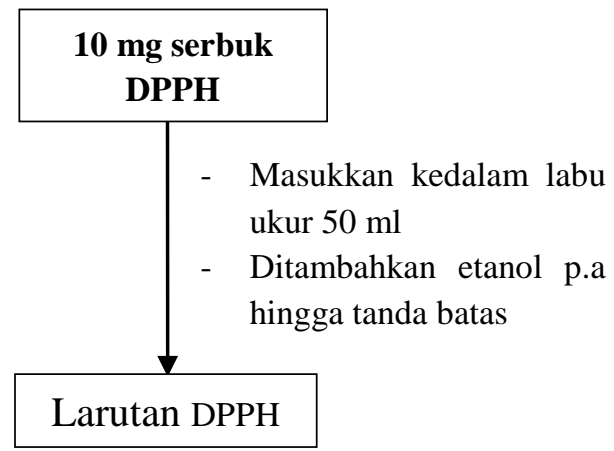

\section{Pembuatan Larutan Sampel}

Ekstrak pekat etanol daun lidah mertua (Sansevieria masoniana Chahin) dibuat menjadi larutan induk 1000 ppm dengan cara melarutkan $25 \mathrm{mg}$ ekstrak kedalam labu ukur $25 \mathrm{~mL}$ dan titambahkan etanol p.a hingga mencapai tanda batas. Setelah didapatkan larutan induk 1000 ppm, kemudian dari larutan tersebut diambil menggunakan mikropipet masing-masing 62,5 $\mu \mathrm{L}, 125 \mu \mathrm{L}, 250 \mu \mathrm{L}, 500 \mu \mathrm{L}, 1000 \mu \mathrm{L}$ kedalam masing-masing labu takar $5 \mathrm{~mL}$. Kemudian akan tambahkan $1 \mathrm{ml}$ larutan DPPH danicukupkan volumenya dengan etanol p.a hingga batas labu takar dalam $5 \mathrm{ml}$. Maka tersedia variasi konsentrasi 12,5, 25, 50, 100, dan 200 ppm untuk uji antioksidan.

\section{Pengukuran Daya Antioksidan Pengukuran Blanko}

1 ml larutan DPPH

- Masukkan kedalam labu ukur $5 \mathrm{ml}$

- Tambahkan etanol p.a hingga tanda batas

- Dihomogenkan

- Dibiarkan 30 menit dalam ruangan gelap

- Ukur absorbansinya pada panjang gelombang $517 \mathrm{~nm}$

\section{Pengukuran Daya Antioksidan Ektrak Daun Lidah Mertua (Sansevieria masoniana Chahin)}

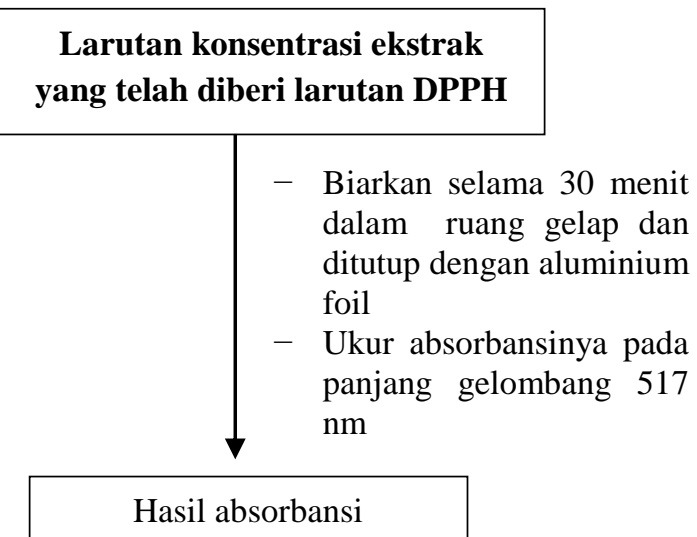

\section{Analisis Data}

Analisis data menggunakan SPSS dengan uji linier regression ANOVA (Analysis of Varian).

\section{HASIL DAN PEMBAHASAN}

Penelitian ini menggunakan daun lidah mertua (Sansevieria masoniana Chahin) yang telah dikering anginkan selama 1 minggu sebanyak 500 gram simplisia. Setelah dilakukan meserasi dan evaporasi ekstrak daun lidah mertua sebanyak $150 \mathrm{ml}$ digunakan untuk uji antioksidan.

Tabel 1. Hasil Skrinig Fitokimia Ekstrak Daun Lidah Mertua (Sansevieria masoniana Chahin)

\begin{tabular}{|l|c|}
\hline \multicolumn{1}{|c|}{ Golongan } & Keterangan \\
\hline Flavonoid & $(+)$ \\
\hline Saponin & $(+)$ \\
\hline Terpenoid & $(-)$ \\
\hline Steroid & $(-)$ \\
\hline Alkaloid & $(-)$ \\
\hline Tanin & $(-)$ \\
\hline
\end{tabular}

Keterangan:
$(+)=$ Mengandung golongan senyawa metabolit sekunder
$(-)=$ Tidak mengandung golongan senyawa metabolit sekunder 
Berdasarkan tabel 1 dapat dilihat hasil pemeriksaan skrining fitokimia ekstrak daun lidah mertua (Sansevieria masoniana Chahin) pada uji flavonoid ekstrak yang ditambahkan $\mathrm{H}_{2} \mathrm{SO}_{4}$ menghasilkan warna merah menunjukkan daun lidah mertua mengandung flavonoid. Pada uji saponin yang ditambahkan Aquadest, Alkohol 96\%, $\mathrm{HCl} 2 \mathrm{~N}$ menghasilkan busa pada tabung uji menunjukkan daun lidah mertua mengandung saponin. Pada uji terpenoid ekstrak yang ditambahkan Liebermenn-Burchard tidak menunjukkan warna merah begitu pula dengan ke-dua metode lain yang menunjukkan daun lidah mertua tidak mengandung terpenoid. Pada uji steroid ekstrak yang ditambahkan Liebermenn-Burchard tidak menunjukkan warna endapan hijau kebiruan begitu pula dengan kedua metode lain yang menunjukkan daun lidah mertua tidak mengandung steroid. Pada uji alkaloid tidak terjadi endapan pada pereaksi bouchardart dan meyer menunjukkan daun lidah mertua tidak mengandung alkaloid. Pada uji tanin ekstrak ditambahkan $\mathrm{FeCl}_{3} 5 \%$ dan tidak terjadi perubahan warna ke biru tua atau hitam kehijauan yang menunjukkan daun lidah mertua tidak mengandung tanin. Sehingga berdasarkan hasil uji fitokimia, daun lidah mertua (Sansevieria masoniana Chahin) memiliki senyawa metabolit sekunder berupa flavonoid dan saponin.

\section{Hasil Uji Aktivitas Antioksidan}

Penentuan nilai aktivitas antioksidan pada ekstrak tanaman lidah mertua ini menggunakan metode serapan radikal bebas DPPH (1,1-difenil-2-pikrihidrazil), alasan penggunaan metode ini dikarenakan pengerjaannya yang sederhana, cepat, dan juga terbukti keakuratannya (Marxen et al. 2007). Semakin besar konsentrasi ekstrak yang diberikan, maka semakin warna ungu dari radikal DPPH akan semakin memudar menjadi pucat kekuningan. Warna berubah akibat elektron bebas pada radikal DPPH berpasangan dengan atom hidrogen yang didonorkan oleh senyawa antioksidan dari ekstrak. Peredaman radikal bebas oleh senyawa antioksidan ini akan membentuk radikal DPPH menjadi stabil dan mengalami pengurangan intensitas warna sehingga menandakan peningkatan aktivitas antioksidan dari ekstrak (Yuhernita dan Juniarti, 2011; Prakash, 2001).

Pada tabel 2 dapat dilihat bahwa semakin kecil nilai absorbansi tiap konsentrasi maka persen peredaman radikal DPPH semakin besar pula. Nilai \% peredaman tertinggi dari ekstrak daun lidah mertua (Sansevieria masoniana Chahin) adalah 77,538. Persentase tersebut mengindikasikan aktivitas DPPH sudah teredam (hilang) sebesar 77,538 pada konsentrasi 200 ppm ekstrak daun Sansevieria masoniana Chahin. Hasil ini menunjukkan ekstrak daun lidah mertua (Sansevieria masoniana Chahin) mampu meredam radikal DPPH dengan baik. Nilai $r$ dari ekstrak daun lidah mertua (Sansevieria 
masoniana Chahin) adalah 0,838 (Gambar 1). Nilai $r$ dari esktrak tersebut mendekati +1 , yang mana menunjukkan $\%$ peredaman memiliki korelasi dengan pemberian konsentrasi ekstrak daun lidah mertua (Sansevieria masoniana Chahin) (Molyneux, 2004).

Pada tabel 3 menunjukkan ekstrak daun lidah mertua (Sansevieria masoniana Chahin) mempunyai nilai $\mathrm{IC}_{50}$ 97,902 ppm. Menurut Syaifuddinn (2015) semakin kecil nilai IC $_{50}$ maka menandakan semakin besar aktivitas antioksidan. Suatu antioksidan termasuk dalam kategori sangat kuat jika nilai IC $_{50}$ kurang dari 50 ppm, antioksidan kuat jika bernilai 50-100 ppm, sedang jika bernilai 101-250 ppm, lemah jika bernilai 251-500 ppm dan dikatakan tidak berpotensi antioksida dengan nilai lebih dari 500 ppm. Ekstrak daun lidah mertua (Sansevieria masoniana Chahin) termasuk kedalam kategori antioksidan kuat dengan nilai $\mathrm{IC}_{50}$ 97, 902 ppm dan dapat dijadikan alternatif sumber antioksidan. Penelitian antioksidan pada spesies sansevieria yang lain menunjukkan aktivitas antioksidan yang lebih kecil dibandingkan dengan antioksidan pada ekstrak daun lidah mertua (Sansevieria masoniana Chahin), yaitu pada ekstrak daun lidah (Sansevieria cylindrica) dengan nilai $\mathrm{IC}_{50}$ sebesar 99,66 ppm (Pratama,2010) dan ekstrak daun lidah mertua (Sansevieria trifasciata) dengan nilai IC $_{50}$ sebesar 100,92 ppm (Mahardika, Hidayat, and Nurika 2014).

Hasil ini diduga berhubungan dengan senyawa metabolit flavonoid yang termasuk golongan senyawa aktif yang memiliki potensi sebagai antioksidan alami (Yuhernita dan Juniarti, 2011).

Senyawa flavonoid dalam ekstrak daun lidah mertua (Sansevieria masoniana Chahin) memiliki kemampuan sebagai antioksidan dikarenakan adanya atom hidrogen pada strukturnya yang dapat didonorkan kepada radikal bebas seperti DPPH sehingga senyawa flavonoid dapat meredam radikal bebas tersebut (Ridho,2013). Senyawa saponin dapat meredam radikal bebas melalui pembentukan intermediet hidroperoksida yang dapat mencegah kerusakan biomolekuler pada tubuh yang disebabkan radikal bebas (Yuhernita dan Juniarti,2011)

Tabel 2. Pengukuran Absorbansi Ekstrak Daun Lidah Mertua (Sansevieria masoniana Chahin).

\begin{tabular}{|c|c|c|c|}
\hline No & $\begin{array}{c}\text { Konsentrasi } \\
(\mathbf{p p m})\end{array}$ & $\begin{array}{c}\text { Rata-rata nilai } \\
\text { absorbansi }\end{array}$ & \% Peredaman \\
\hline 1 & Blanko & 0,9732 & 0 \\
\hline 2 & 12,5 & 0,8099 & 16,77969585 \\
\hline 3 & 25 & 0,7899 & 18,83477189 \\
\hline 4 & 50 & 0,5097 & 47,62638718 \\
\hline 5 & 100 & 0,3405 & 65,01233046 \\
\hline 6 & 200 & 0,2186 & 77,53801891 \\
\hline
\end{tabular}


Tabel 3. Nilai $\mathrm{IC}_{50}$ ekstrak daun lidah mertua (Sansevieria masoniana Chahin).

\begin{tabular}{|c|c|c|c|c|}
\hline No & $\begin{array}{c}\text { Konsentrasi } \\
\text { ekstrak daun lidah } \\
\text { mertua }(\mathrm{ppm}) \\
\end{array}$ & $\begin{array}{c}\text { \% Peredaman } \\
\text { DPPH }\end{array}$ & $\begin{array}{c}\text { Persamaan Garis } \\
\text { Linear }\end{array}$ & Nilai IC $_{50}$ \\
\hline 1 & Blanko & 0 & \multirow{6}{*}{$\begin{array}{c}\mathrm{Y}=13,66+0,371 \mathrm{x} \\
\mathrm{R}^{2}=0,838\end{array}$} & \multirow{6}{*}{$\begin{array}{c}97,902 \\
\text { ppm }\end{array}$} \\
\hline 2 & 12,5 & 16,77969585 & & \\
\hline 3 & 25 & 18,83477189 & & \\
\hline 4 & 50 & 47,62638718 & & \\
\hline 5 & 100 & 65,01233046 & & \\
\hline 6 & 200 & 77,53801891 & & \\
\hline
\end{tabular}

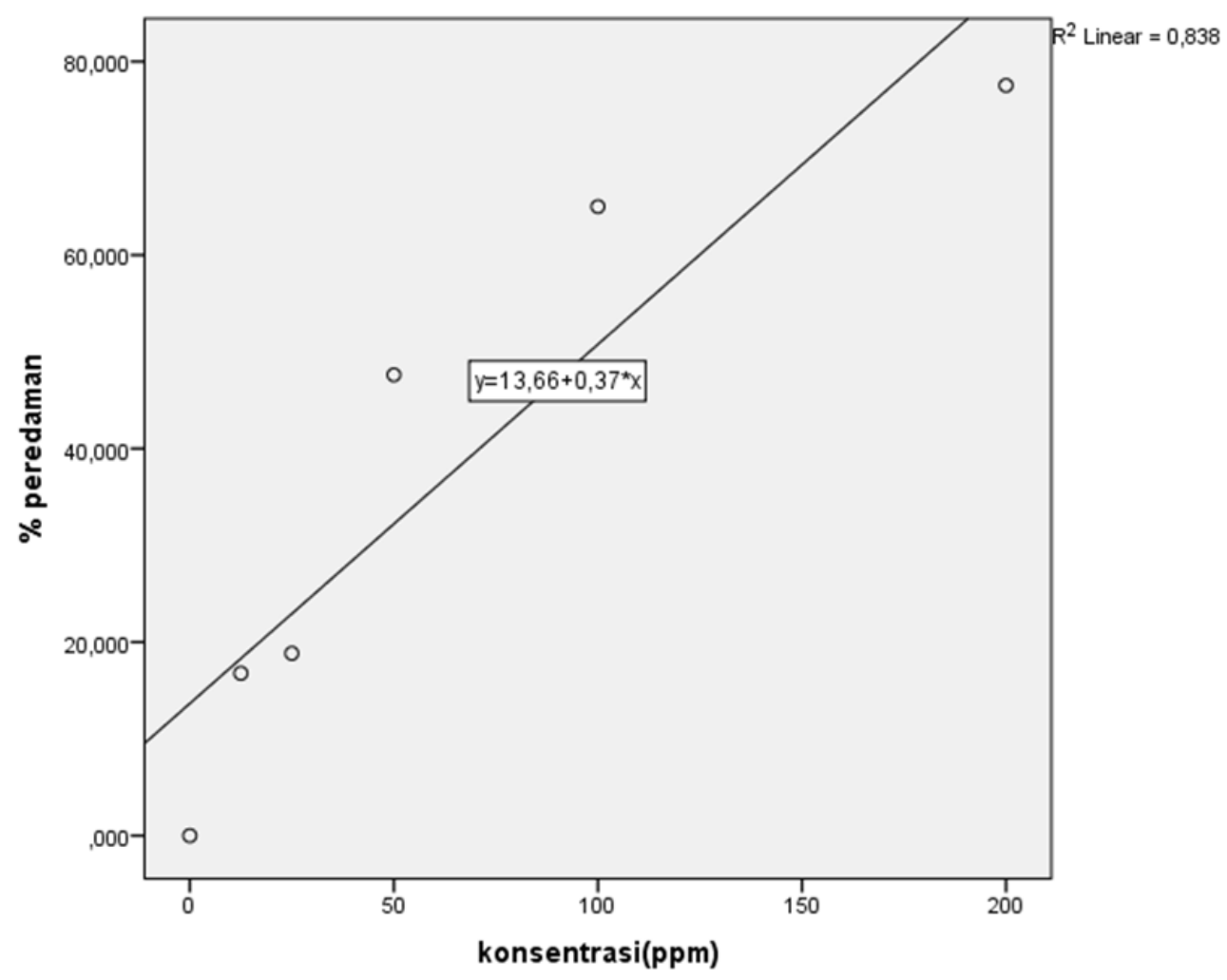

Gambar 1. Kurva Regresi Linier Ekstrak Daun Lidah Mertua (Sansevieria masoniana Chahin)

\section{KESIMPULAN}

Berdasarkan hasil penelitian yang telah dilakukan dapat disimpulkan bahwa :

1. Kandungan metabolit sekunder yang terdapat dalam ekstrak daun lidah mertua (Sansevieria masoniana Chahin) adalah senyawa flavonoid dan saponin.

2. Ekstrak daun lidah mertua (Sansevieria masoniana Chahin) memiliki aktivitas antioksidan yang kuat dengan nilai $\mathrm{IC}_{50}$ 97,902 ppm.

\section{DAFTAR PUSTAKA}

Aji R.M. 2014. Uji Aktivitas Antioksidan pada Ekstrak Daging Daun Lidah Buaya (Aloe vera) Menggunakan Metode DPPH (1,1-Diphenil-2- Picrylhydrazyl). Skripsi. UIN Syarif Hidayatullah Fakultas Kedokteran dan Ilmu Kesehatan, Jakarta. 
Aqil, Farrukh, Iqbal Ahmad, and Zafar Mehmood. 2006. "Antioxidant and Free Radical Scavenging Properties of Twelve Traditionally Used Indian Medicinal Plants." Turkish Journal of Biology 30(3):177-83.

Handayani, Virsa, Aktsar Roskiana Ahmad, and Miswati Sudir. 2014. "Uji Aktivitas Antioksidan Ekstrak Metanol Bunga Dan Daun Patikala (Etlingera Elatior (Jack) R.M.Sm) Menggunakan Metode DPPH." Pharmaceutical Sciences and Research 1(2):86-93.

Hayati.A. 2011. Spermatologi. Pusat Penerbitan dan Percetakaan Unair.Surabaya.

Harborne,J.B., (1987). Metode Fitokimia; Penuntun Cara Modern Menganalisa Tumbuhan. Bandung: ITB Press

Ismail, Jefriyanto, Max R. .. Runtuwene, and Feti Fatimah. 2012. "Penentuan Total Fenolik Dan Uji Aktivitas Antioksidan Pada Biji Dan Kulit Buah Pinang Yaki (Areca Vestiaria Giseke)." Jurnal Ilmiah Sains 12(2):84.

Jin, Lei, Yanlong Zhang, Linmao Yan, Yulong Guo, and Lixin Niu. 2012. "Phenolic Compounds and Antioxidant Activity of Bulb Extracts of Six Lilium Species Native to China." Molecules 17(8):936178.

Julfitriyani., Max, R.R., \& Defny W. 2016. Uji Aktivitas Antioksidan dan Toksisitas Ekstrak Etanol Daun Foki Sabarati (Solanum torvum). Jurnal Ilmiah Farmasi Pharmacon. 5: 95-101.

Mahardika, R. Ayu Dini, Nur Hidayat, and Irnia Nurika. 2014. "Ekstraksi Antioksidan Dari Lidah Mertua (Sansevieria trifasciata Prain) Menggunakan Metode Microwave Assisted Extraction Dan Pulsed Electric Field Ekstraksi Antioksidan Dari Lidah Mertua ( Sansevieria Trifasciata Prain )
Menggunakan Metode Microwave Assi." (sanseviera):1-10.

Marmi, Gizi dalam Kesehatan Reproduksi, (Yogyakarta: Pustaka Pelajar, 2013)

Marxen, Kai, Klaus Heinrich Vanselow, Sebastian Lippemeier, Ralf Hintze, Andreas Ruser, and Ulf-peter Hansen. 2007. "S7102080.Pdf." 2080-95.

Molyneux, Philip. 2004. "The Use of the Stable Free Radical Diphenylpicryl-Hydrazyl (DPPH) for Estimating Antioxidant Activity." Songklanakarin Journal of Science and Technology 26(December 2003):211-19.

Pratama, Rahadian, Departemen Biokimia, Fakultas Matematika, D. A. N. Ilmu, and Pengetahuan Alam. 2010. "Potensi Antioksidan Dan Toksisitas Ekstrak Daun Sansevieria Cylindrica."Skripsi. Institut Pertanian Bogor.FMIPA.

Pratimasari, Diah. 2009. "Uji Aktivitas Penangkap Radikal Buah Carica papaya L Dengan Metode Dpph Dan Penetapan Kadar Fenolik Serta Flavonoid Fakultas Farmasi." Dissertation, Univerversitas Muhammadiyah, Surakarta.

Prakash A, (2001). Antioxidant Activity, Medallion Laboratoris Analytical Progress, 19(2), Sunarni,T., 2005, Aktivitas Antioksidan Penangkap Radikal Dari Daun Kepel (Stelechocarpus Burahol),Jurnal Farmasi Indonesia, 2 (1),15.

Ridho, E. A., (2013). Uji Aktivitas Antioksidan Ekstrak Metanol Buah Lakum (Cayratia Trifolia) Dengan Metode DPPH. Naskah Publikasi, Program Studi Farmasi, Fakultas Kedoketeran Universitas Tanjung Pura Pontianak.

Syaifuddin, S. 2015. Uji Aktivitas Antioksidan Bayam Merah (Alternanthera amoena voss.) Segar dan Rebus dengan Metode 
DPPH. Dissertation, UINWalisongo. Semarang.

Tamat, Swasono R., Thamrin Wikanta, and Lina S. Maulina. 2007. "Aktivitas Antioksidan Dan Toksisitas Senyawa Bioaktif Dari Ekstrak Rumput Laut Hijau Ulva Reticulata Forsskal." Jurnal Ilmu Kefarmasian Indonesia 5(1):31-36.

Tapan, E, 2005, Kanker, Antioksidan, dan Terapi Komplementer, Gramedia. Jakarta.

Umayah, E.U. \& Amrun. 2007. Uji Aktivitas Antioksidan Ekstrak Buah Naga (Hylocereus Undatus (Haw.) Britt. \& Rose). Jurnal Ilmu Dasar, 8: 83-90.

Widowati, Wahyu(Pusat Penelitian Ilmu Kedokteran). 2011. "Uji Fitokimia Dan Potensi Antioksidan Ekstrak Etanol Kayu Secang ( Caesalpinia Sappan L .).” Jurnal Kedokteran Maranatha 11(65):23-31.

Wahdaningsih,P., Setyowati, E.P., Wahyuono, S. (2011). Aktivitas Penangkap Radikal Bebas Dari Batang Pakis (Alsophila glauca J.Sm). Majalah Obat Tradisional, 16(3)156-160.

Winarsih, H, 2007, Antioksidan Alami dan Radikal Bebas, Kanisius. Yogyakarta.

Whika Febria Dewatisari, Leni Rumiyanti, Ismi Rakhmawati, J1 Soekarno, and Hatta No. n.d. "Rendemen Dan Skrining Fitokimia Pada Ekstrak Daun Sanseviera Sp . Rendemen and Phytochemical Screening Using Leaf Extract Of.” 17(3):197-202.

Yuhernita dan Juniarti. 2011. "Analisis Senyawa Metabolit Sekunder Dari Ekstrak Metanol Daun Surian Yang Berpotensi Sebagai Antioksidan." MAKARA of Science Series 15(1):48-52. 